\title{
Thoughts about the Cultivation of Students' Innovative Consciousness and Innovative Ability During the Professional Course Teaching
}

\author{
Fei Li \\ School of Education Science, Tonghua Normal University, Tonghua, China \\ lifei1129@126.com
}

\begin{abstract}
Keywords: Innovative education; Innovative consciousness; Innovative ability; Teaching reform; Teaching evaluation
\end{abstract}

\begin{abstract}
Carrying out innovative education is the duty and mission of higher education, given by the era. Carrying out the thinking and exploring to the cultivation of students' innovative consciousness and innovative ability during the professional course teaching has great significance to improve the quality of innovation education in higher education. Only on the basis of envisaging the present problems, taking positive change in the concept of education, expanding the education content, strengthening the construction of teachers, reforming the teaching methods, digging the curriculum innovation education content, reconstructing the scientific teaching evaluation system, promoting the innovation thinking. Then, it can really make the cultivation of students' innovation consciousness and innovation ability to be implemented.
\end{abstract}

\section{Introduction}

As early as 1998, Jiang Zemin, the general secretary of china, pointed out that "innovation is the soul of a nation and an inexhaustible motive force for the country's prosperity"[1]. Sixteen years later, on the Davos Summer Forum, Li Keqiang, Premier of the State Council of the People's Republic of China, proposed to raise a new tide of mass entrepreneurship, grassroots entrepreneurship, and to format the new situation of innovation for all. And then, in June 11,2015, the State Council promulgated a series of polices and measures to promote innovation. Many measures were made shown the government's efforts to promote innovation and entrepreneurship. If we want to innovate, we must have talented people who can innovate, and the training of innovative talents must be carried out. So, to carry out innovative education is the time entrusts with the glorious mission of education, the value orientation of innovation education it is necessary to set up promoting education innovation consciousness, innovation spirit and courage and innovation ability, and solve the issues about training students' innovation consciousness, innovation spirit and innovation ability especially in the process of education [2].

\section{The Problems in Current Innovation Education of Colleges and Universities}

Since the general secretary Jiang Zemin at the third National Conference on education pointed out in his speech: "education in cultivating national spirit of innovation and cultivate innovative talents is shouldering the special mission", many educators have paid extensive attention to and research on the cultivation of students' innovative consciousness and ability. But there still existed some problems in the cultivation of students' innovative consciousness and ability, such as: more theoretical exposition than practice verification, more innovative forms than innovation content, more extracurricular innovation than in-class innovation, more basic innovation than high-level innovation[3].

Traditional Teaching Model and Examination Oriented Education System. As a whole, the pace of innovation education reform in China's institutions of higher learning is still relatively slow. "Warehouse theory" still prevails in our educational practice[4]. The students of the brain as educators to store knowledge warehouse, in the process of teaching too much emphasis on the teaching of existing knowledge, to test knowledge of main memory, the requirements for talents in the teaching method and the new age quite inconsistent. 
There Still Existed Some Shortages of Setting Up the Profession and Course. Most of the graduates thought the most important thing in college was learning the basic theory firmly, cultivating comprehensive quality. They thought the knowledge studying in the college was mismatching the social demands. These problems prolong their social adaptation period, and limited their development[5].

A variety of reasons lead to the weakness of students' creative consciousness. The lack of innovative consciousness among students is a serious disease in higher education[6]. There are many reasons for this situation, such as: the negative influence of obedient Education, the regular teaching methods, and teaching ignores theory and practice, and lacks the cultivation of practical ability.

\section{Ways and Strategies to Break Through the Current Predicament}

Innovative ability is an important aspect of College Students' comprehensive quality. Innovative education is the key point of the current reform of higher education. We believe that innovative education should be made in the following aspects.

Firstly, Changing the Educational Concept Actively and Broadening the Content of Education. Innovation education, as a new and advanced educational thought and idea, needs to be supported by scientific theories and concepts. We must keep pace with the times, timely reflect and transform the traditional concept of education. We must upgrading the education concept which was unsuitable to the modern social talents training, ensure that educational philosophy is consistent with the needs of modern society. We should generate new education view, learning view and talent view. We should pay attention to the educational concept of cultivating innovative spirit and innovative ability, and pay attention to the idea of cultivating talents with multiple abilities and comprehensive development, paying attention to highlighting the principal position and function of students' learning[7]. On one hand, helping students to develop a correct outlook on learning. For students, the innovative ability includes practical ability and new ideology, and the cultivation of innovative ability has a direct relationship with the opening of specialized courses. Only by defining the purpose of specialized courses can we devote more time and energy to the training of innovative ability in the course of specialized courses. Also, in the process of teaching, we should improve the students' understanding of the creative ability. Only when students realize the importance of innovation ability can they excavate and improve their own creative ability spontaneously. On the other hand, teachers should set up a correct view of education. In the course of teaching professional courses, teachers should firmly implement the principal position of students, arouse their enthusiasm and participation. Teachers should update the teaching concept, establish a lifelong learning attitude, learning new knowledge and methods to treat the courage to learn and try to get rid of old teaching ideas, to develop their own teaching thinking to keep up with education. Further more, creating a teaching environment conducive to improving students' innovative ability, create teaching situations and stimulate awareness of problems. In the teaching process, follow the "thinking in question" principle, advocate thinking without penalty area, advocate the debate, continue to strengthen their "problem consciousness", to create a good, free and harmonious learning atmosphere, let students freely, bold opinions and ideas, and dare to doubt, dare to create.

Secondly, Strengthening the Construction of Teaching Staff, Reforming Teaching Methods. A fine example has boundless power. To the educated, the role of the teacher's model is particularly critical. Therefore, if we want to implement innovative education, we must give full play to the exemplary role of teachers. Only the teachers having innovative consciousness, innovative spirit and innovative ability, they can give enough demonstration to students, give full play to the power of example. Therefore, teachers attach importance to the development of their own innovative ability. Innovative education calls for innovative teachers, only having the innovative consciousness and innovation ability, teachers will be to break the shackles of the old mode, daring to improve teaching methods and apply the modern teaching methods, pay attention to the creation of a democratic, establish free and harmonious teaching environment, according to their characteristics, advantages and characteristics of the subject, to create their own teaching style. So as to realize the cultivation of students' innovative consciousness and innovation ability goals[8]. In the process of professional course teaching, teachers should be encouraged to consciously use innovative consciousness, innovative 
thinking and innovative ability to influence and promote students, so that students can continuously enhance their innovative consciousness and develop their innovative ability. Actively using the group discussion method, independent inquiry learning method, to promote the development of students' autonomy, initiative and creativity, so that they will generate self initiated, self selection, self organization, self guidance, independent thinking and self evaluation ability. Helping them to form the ability of evaluating the different opinions, increasing the courage of making judgment. At the same time, we can actively design open exercises, train divergent thinking, and cultivate the broadness, flexibility and creativity of thinking.

Thirdly, Allocating the Curriculum Content System Reasonable, Highlighting Innovation Tendencies. The construction and establishment of curriculum content system is the core of curriculum teaching, and also the key to achieve the goal of talent training[9]. In order to carry out innovative education, we must construct innovation oriented curriculum system, take cultivating the ability of acquiring knowledge, applying knowledge as the curriculum objectives. We also must pay more attention to explore the innovation factors of teaching materials, cultivate students' innovative ability. First of all, teachers should set up a strong curriculum awareness, establish the curriculum guiding ideology which meets the requirements of innovative education, and make the curriculum truly realize its openness, democracy and Science in its essential sense. And then, teachers should strengthen the construction of activity courses and integrated courses, and train students' ability to apply knowledge comprehensively and solve problems[10]. The school must organize teachers, content of the activity curriculum and integrated curriculum form, characteristics and other aspects of careful research and thinking, in full consideration of the students physical and mental development and cognitive development law, scientific and systematic mining activity curriculum and integrated curriculum create points, a reasonable set of links, creating situations, teaching innovation methods, give full play to the integrated curriculum and activity curriculum in cultivating students' innovation ability, promote the healthy development of great role. In the last, increase and enlarge the proportion of elective courses, make the students' personality develop as fully as possible, and help to cultivate their innovative consciousness and ability.

Fourthly, Reconstructing Educational Evaluation System to Promote Creative Thinking. Education evaluation is an important way to test the education effect, and an important method to judge whether the school education reform is effective or not. Under new situations and circumstances, the traditional education evaluation system and mechanism didn't apply to the requirements of innovative education[11]. In order to give full to the guidance and incentive role of the evaluation system for innovative education, we need to do the following things. On one hand, the education administration department should change the evaluation orientation of school running, it's means to bring innovation education into the evaluation system, which included traditional evaluation index, such as school quality, school conditions and school environment. On the other hand, according to the evaluation system and requirements of the higher education administration department, the school should setup an evaluation strategy which conforms to the actual situation of the school and give prominence to encouragement, for example, to increase the proportion of teachers' innovative ability and innovative performance, and to pay attention to the innovative performance of teachers in the teaching process[12]. Further more, we should think highly of the developing evaluation, emphasize the promoting role of formative assessment, strive to improve the scientific and practicality of the innovative education evaluation standard. Using multilevel and systematic evaluation methods, such as school innovation education, management work evaluation, teacher innovation education evaluation and student innovative learning evaluation method.

\section{Summary}

In a word, school education has the irreplaceable effect to improve the basic quality of the people and enhance the masses' level of education. The course teaching is also an important way and approach to bring into full the functions of school education, to achieve the purpose of education. Therefore, it is 
necessary to think and explore the innovative consciousness and innovative ability of the students, in the professional course teaching.

\section{Acknowledgments}

This work was financially supported by the Teaching Reform Research Project of Tonghua Normal University.

\section{References}

[1] S.L.Zhang:Education Exploration, Vol. 21(2011) No.10, p.53-55.(In Chinese)

[2] B.Sang and Y.D.Zhou:Journal of Ningbo University (Educational Science Edition) Vol.33(2011) No.2,p.52-56.(In Chinese)

[3] Z.Zhang:Ability And Wisdom,Vol.12(2017) No.8,P.135.(In Chinese)

[4] Z.Q. Hong: A Study of University Teaching Administration on the Background of Innovative Education (MS., Central China Normal University, China 2002), P.28.(In Chinese)

[5] B.Xi:Modern Education Management,Vol.31(2013)No.7,p.40-43.(In Chinese)

[6] J.K. Li and Z.Q. Zhang: Beijing Education,Vol.22(2015)No.5, p.21-23.(In Chinese)

[7] J.C. Liu: Forum on Contemporary Education,Vol.11(2012) No.5,p.34-37.(In Chinese)

[8] Information on http://www.snedu.gov.cn/jynews/rdjj/201707/04/69190.html(In Chinese)

[9] W.Wang: Education Review,Vol.31(2015)No.8,p.86-88.(In Chinese)

[10] Information on http://www.ncss.org.cn/tbch/cxcyjyzt/(In Chinese)

[11] Y.C.Zhang, Y.J.Niu, S.H.Tang and H.X.Qin: Journal of Henan Science and Technology, Vol.38(2013)No.2,p.275.(In Chinese)

[12] C.Q.Qin and Y.Feng: China Adult Education,Vol.22(2013)No2,p.12-14.(In Chinese) 